\title{
Organizational Culture and Employees Compliance in Comestible Manufacture Company
}

\author{
Rosa Almira Elisse Samantha Ish ${ }^{1}$, Rina Anindita ${ }^{2}$ \\ Universitas Esa Unggul, Jakarta Indonesia ${ }^{1,2}$
}

\begin{abstract}
Organizational culture is important for comestible manufacture company in Indonesia to establish employees compliance, so that this study to find how the level of organizational culture in comestible manufacture company in Indonesia by employee compliance level to regulation. This Studied conducted in September-December 2018 by distributed questionnaires to 370 respondents who permanent employees of comestible manufacture company in Jakarta, Bogor, Depok, Tangerang, Bekasi (Indonesia) and surroundings. The research method used validity tested, reliability tested, categorization on organizational culture and employee compliance variables. Researcher also conducted comparative analysis at the level of employee's compliance in organizational culture to see the difference between the employee's compliance level and employee's compliance aspects. The results showed organizational culture in comestible manufacture company in Indonesia is in medium category. The level of compliance on comestible manufacture company employees in Indonesia also in medium category.
\end{abstract}

Keywords: Organizational Culture, Employee Compliance, Comestible manufacture company, Indonesia

\section{INTRODUCTION}

Organization's culture form is the desired environment of the company, and become a control system in the social environment that can affect employees to show work attitudes that are in accordance to the company's values. So if you want to form an organization that leads to profitable company values and goals, you can build a positive and strong organizational culture. According to Schein (2010) the impact from individuals organizational culture are behavior and attitudes, so it will always be related to company performance. Organizational culture controls the behavior and attitudes of employees. Organizational culture increase a sense of commitment to the organization, so it will improve compliance, performance, creativity. Employee can also be used as a benchmark for the health or failure of a company. According to Robbins and Judge (2015) organizational culture as a mechanism for making a meaning and control that forms attitudes and behavior of employees. So that by showing a positive organizational culture it can provides positive perceptions for employees so it will encourage employees to make deeper contributions while working. Mesako (2017) explained there are two types of organizational culture in the company, they are, strong and weak organizational culture. Strong culture is more profitable company, which playing the role in development of the company in terms of financial strength, and the level of productivity. Research by Pribadi and Herlena (2016) on employees of the Production Directorate on Steel manufacture in Cilegon, Indonesia has an organizational culture on medium category of innovative aspects and discipline. In McKinsey report by Sull (2015) it was stated that many had begun to strengthen their organizational culture by increasing innovation and compliance, such as Lego companies, Zumba Fitness and Zatini Catering Group. So that, strong organizational culture is very important for a company.

Chen (2008) studied revealed that there are still many companies in China that place organizational culture as a formality without meaning when compared to other countries and are strongly influenced by the culture of the country itself. One of them in terms of culture manages the risk of failure, and its not norm in China so lacks tolerance. On McKinsey report (2016) also shows that companies in Korea also diagnosed as having a weak work culture. Reaching $25 \%$ of companies in Korea has serious organizational culture issues, and more than $60 \%$ of companies are indicated problems related to organizational culture characterized by injustice for female workers, authoritarian leadership, partiality in a group, injustice evaluation and reward systems, weak rewards remuneration, and operational discipline.

Research conducted by Damayanti and Fakhri (2013) on weak organizational culture also has a problem in discipline employees. In a studied by Irawati and Silalahi (2015) manufacturers also have a discipline problem and not obey to the company rules. Based on observation and interview, PT. GMK is one of the comestible manufacture company in Indonesia also face its problems too. So that the organizational culture and employee compliance still become a problem in Indonesia. Therefore, researcher is interested in examining how organizational culture in comestible manufacture company viewed from employee compliance level. 


\section{International Advanced Research Journal in Science, Engineering and Technology}

Vol. 6, Issue 4, April 2019

The purpose of this study is to find how the level of organizational culture in comestible manufacture company and also knowing how organizational culture level in terms of aspects of innovation and risk taking, attention to detail, orientation towards results, orientation to the team, orientation towards individuals, aggressiveness, and stability. Furthermore, the purpose of this study isto find how the level of employees compliance with comestible manufacture company regulations in Indonesia and how levels of employee compliance in terms of environmental conformity in comestible manufacture company in Indonesia.

\section{LITERATURE REVIEW}

Organizational culture according to Robbins and Judge (2015) is a value system held by members of the organization that differentiates from one organization to another. From some of the above meanings it can be concluded that organizational culture is defined as trust and hope along with all members of the organization that distinguish one organization from another. Whereas according to Kreitner and Kinichi (2014) the function of organizational culture can provide organizational identity to employees, and also facilitate collective commitment.

According to Robbins and Judge (2015), there are seven indicators of Organizational culture indicators. First, innovation and risk taking is the extent to which organizations encourage employees to be innovative and take risks. Second, Attention to detail is the extent to which the organization expects employees to show accuracy, analysis and attention to details. Third, the result orientation is the extent to which management focuses on results rather than attention to the techniques and processes used to achieve this. Fourth, Orientation to individuals is the extent to which management decisions take into account the effects of results on people in the organization. Fifth,The orientation of the team is the extent to which work activities are organized around teams, not individuals. Sixth, Aggressiveness is the extent to which people in the organization are aggressive and competitive to carry out the best organizational culture. Seventh, stability is the extent to which organizational activities emphasize the status quo rather than growth.

Brown (2009) said there are nine ways that workers can do to study organizational culture. They are, by looking at the artifacts, that, patterns of behavior, norms of behavior, heroism, symbols and symbolic actions, values and ways of thinking, asusmsi base, and history. According to Robbins and Judge (2015) the values contained in organizational culture are leadership, attitudes, rules. So that rules and norms of behavior such as compliance are related to organizational culture

Franklin and Pagan (2016) also explained that work discipline is a compliance in carrying out work with company rules and standards. According to Milgram (1963) compliance is related to obedience to the authority of the rules. Compliance is defined by Kelman (1958) as behaviors following the authority's request even though individuals individually don't agree with the request. Blass (1999) dimensions of compliance are belief, accept and act. Frederich (2012) said in compliance there are three forms of behavior. They are conformity, compliance, and obedience.

Indonesian industrial constitution on 5 number, 1984 explain industry is economic activity that processes raw materials, finished goods, and/or finished goods into goods of higher value for their use, including industrial design and engineering activities. In this study carried out on the food raw material industry. According Salamadian (2017) industry universal category based on the International Standard of Industrial Classification (ISIC) approach of commodity groups, so in this research conducted on comestible manufacture company.

\section{HYPOTHESIS AND FRAMEWORK DEVELOPMENT}

Results of McKinsey report in Xiaoming et al. (2012) companies in China don't have the difference in organizational identity from other organizations. In the McKinsey report (2016), found that, Korea is having a weak work and operational discipline less implemented. Jaghargh et al. (2012) explained that organizational culture can shape the desired environment of the company and become a control system in the social environment that can affect employees to show work attitudes that in the line with the value of the company. In the McKinsey report carried out by Sull (2015) which resulted that there are several companies abroad have now begun to strengthen their organizational culture by increasing innovation, such as applying simple rules to be obeyed. This leads to innovation and holding back the bureaucracy to complicate regulations that trigger chaos.

In the research conducted by Noonan (2017) the United State (US) tends to apply culture more on time, and adhere to regulations when working compared to the United Kingdom (UK). Franklin and Pagan (2016) explains that work discipline is a form of compliance in carrying out work in accordance with company rules and standards. Other research was conducted by Damayanti and Fakhri (2013) at PT AngkasaPura II (Persero) culture organization has a positive and significant influence on work discipline. According to the research conducted by Pribadi and Herlena (2016) the type of organizational culture that employees influences the increasing attitudes and behavior of work discipline which is marked by obedient compliance with the applied regulations. Pribadi and Herlena (2016) shows organizational culture gives effect to employee discipline, such as compliance on work regulations. This is a figure of the framework in this study, as follow : 


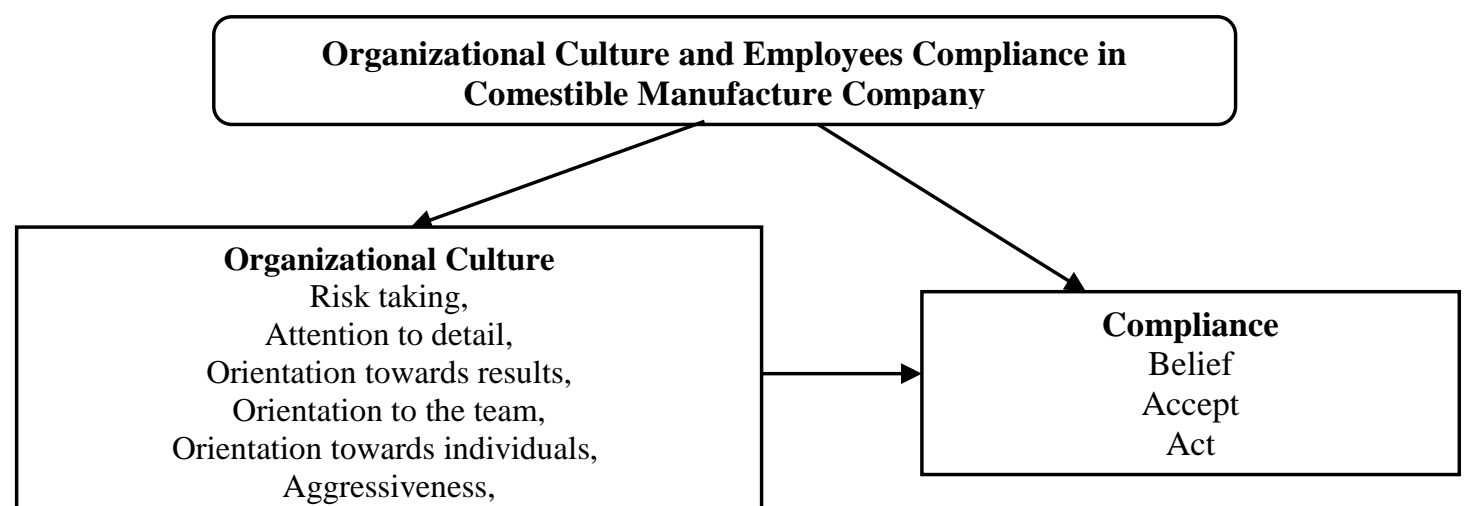

Figure 1.1 Framework

Based on framework, hypothesis of this research is in comestible manufacture company have a strong organizational culture, the level of employee compliance will be higher.

\section{RESEARCH METHOD}

This Study is a descriptive quantitative to explained and answered the hypothesis. Study instruments were used to measure the value of variables to describe the aspects studied. The types and sources of data used are primary data such as interview and organizational culture and employee compliance questionnaires, and secondary data such as employee attendance. The method of measurement is used a Likert scale, by given a score of 4 on the SS choice, score 3 to S choice, score 2 on TS choice, and score 1 to STS choice in the organizational culture and employee compliance questionnaire.

The population in this study were 126 comestible manufacture company in Indonesia which was included on Indonesian Food and Beverage Association Members 2018 (GAPPMI). Based on Krejcie and Morgan (1970) table has 10,000 employee arrounded on comestible manufacture company, so in this studied was taken by 370 respondents on comestible manufacture company in Jabodetabek such as PT. Gandum Mas Kencana, PT. Zeelandia Indonesia, PT. Seelindo Sejahteratama, PT. Olinda Boga Buana, PT. INCA, PT. Bumitangerang Mesindotama (BT Cocoa), PT. NIPPN Foods Indonesia, PT. Antaka Rasa, and PT. Kobe Boga Utama with Non-Probability Sampling technique requirements are permanent employees of comestible manufacture and knowing how the company organizational culture related to employee compliance.

To validity and relability questionnaire tested, researcher used a statistics tools, and methods processed a categorisation of organizational culture, employee compliance variable and also aspects of conformity. This study also discussesed the profile of research objects based on age, gender, education, work periode, work position to support the demographics in this studied. Its also conducted comparative analysis the level of employees compliance in organizational culture to see how different of compliance employees level and employee compliance aspects with the organization's culture by divided into two groups is high and low, so that the high and low to see more clearly.

\section{RESULTS AND DISCUSSION}

Organizational culture. To make it easier results discuss, researcher grouping the categories very strongly and strongly into strong categories, and weak and very weak become weak categories in each discussion. To determine the category limits, the standard deviation and average values are used. The organizational culture variable has a minimum theoretical value for organizational culture is 49 , while the maximum value is 108 . The mean $(\mu)$ is 84.38 and the standard deviation value $(\boldsymbol{\sigma})$ is 9.46 . Following table 1. Organizational Culture Categorization, as follows:

Table 1 Organizational Culture Categorization

\begin{tabular}{cccc}
\hline Score Limit & Score & Categorization & Total \\
\hline $\mathbf{X}>(\boldsymbol{\mu}+\mathbf{1 . 5} \boldsymbol{\sigma})$ & $\mathrm{X}>98.57$ & Very strong & $34(9.19 \%)$ \\
\hline$(\boldsymbol{\mu}+\mathbf{0 . 5} \boldsymbol{\sigma})<\mathbf{X} \leq(\boldsymbol{\mu}+\mathbf{1 . 5} \boldsymbol{\sigma})$ & $89.11<\mathrm{X}<98.57$ & Strong & $55(14.87 \%)$ \\
\hline$(\boldsymbol{\mu}-\mathbf{0 . 5} \boldsymbol{\sigma})<\mathbf{X} \leq(\boldsymbol{\mu}+\mathbf{0 . 5} \boldsymbol{\sigma})$ & $79.65<\mathrm{X}<89.11$ & Medium & $189(51.08 \%)$ \\
\hline$(\boldsymbol{\mu}-\mathbf{1 . 5} \boldsymbol{\sigma})<\mathbf{X} \leq(\boldsymbol{\mu} \mathbf{- 0 . 5} \boldsymbol{\sigma})$ & $70.19<\mathrm{X} \leq 79.65$ & Weak & $74(20 \%)$ \\
\hline $\mathbf{X} \leq(\boldsymbol{\mu} \mathbf{- 1 . 5} \boldsymbol{\sigma})$ & $\leq 70.19$ & Very weak & $18(4.86 \%)$ \\
\hline & TOTAL & & $\mathbf{3 7 0}(\mathbf{1 0 0 \%})$ \\
\hline
\end{tabular}




\section{International Advanced Research Journal in Science, Engineering and Technology}

Vol. 6, Issue 4, April 2019

Organizational culture in comestible manufacture company on medium category with the most respondents are 189 respondents $(51.08 \%)$. Whereas 89 respondents $(24.06 \%)$ considered having a strong organizational culture and 92 respondents $(24.86 \%)$ considered their organizational culture to be weak. According to Schein (2010) organizational culture group in medium category is a cultural segment which shows there are still differences in the norms, values, beliefs and behavior of a person in the goals of his organization.

For example, companies active do the aspects of innovation and risk-taking, aggressiveness, stability but lack priority on orientation to team because the work culture in the company gives more jobs in individual targets. Winter (1984) said that applying a consistent and strong organizational culture is not easier. So that in this study alsoin medium category. The other hands, respondents factors of who have a 1-3 working period that they understand the organizational culture that is applied, but are not optimal in carrying out it.

For weak organizational culture according to Deal and Kennedy (1982) it is explained that the weakness of organizational culture is looseness, or looseness that no one can follow strict rules and a gap that separates one's objectivity from organizational goals. So that companies are still not found in forming a rigorous work environment, or oriented towards work results.

On strong organizational culture, Sterwart (2010) explains that a strong organizational culture is a part of strengthening employees because it has equated and grasped the beliefs and values from the focus of the organization. And provide strong affection and attachment to the organization. So that, companies reflect how oriented they are to building innovation and being responsible for risk, maintaining work quality to minimize failed products. In addition, the company continues to be oriented towards each employee in determining a decision, maintaining maximum work results and also maintaining team collaboration to remain solid in comestible manufacture company that meet the production target. The Following Table 2. Organizational Culture Categorization on Aspects of Innovation and Risk Taking:

Table 2.Organizational Culture Categorization on Aspects of Innovation and Risk Taking

\begin{tabular}{cccc}
\hline Score Limit & Score & Categorization & Total \\
\hline $\mathbf{X}>(\boldsymbol{\mu}+\mathbf{1 . 5} \boldsymbol{\sigma})$ & $>15.40$ & Very strong & $39(10.54 \%)$ \\
\hline$(\boldsymbol{\mu}+\mathbf{0 . 5} \boldsymbol{\sigma})<\mathbf{X} \leq(\boldsymbol{\mu}+\mathbf{1 . 5} \boldsymbol{\sigma})$ & $13.61<\mathrm{X} \leq 15.40$ & Strong & $72(19.46 \%)$ \\
\hline$(\boldsymbol{\mu} \mathbf{- 0 . 5} \boldsymbol{\sigma})<\mathbf{X} \leq(\boldsymbol{\mu}+\mathbf{0 . 5} \boldsymbol{\sigma})$ & $11.83<\mathrm{X} \leq 13.61$ & Medium & $194(52.43 \%)$ \\
\hline$(\boldsymbol{\mu} \mathbf{- 1 . 5} \boldsymbol{\sigma})<\mathbf{X} \leq(\boldsymbol{\mu} \mathbf{- 0 . 5} \boldsymbol{\sigma})$ & $10.04<\mathrm{X} \leq 11.83$ & Weak & $35(9.46 \%)$ \\
\hline $\mathbf{X} \leq(\boldsymbol{\mu} \mathbf{- 1 . 5} \boldsymbol{\sigma})$ & $\mathrm{X} \leq 10.04$ & Very weak & $30(8.11 \%)$ \\
\hline & TOTAL & & $\mathbf{3 7 0}(\mathbf{1 0 0 \%})$ \\
\hline
\end{tabular}

Organizational culture in comestible manufacture company on innovation and risk taking aspects are greater in the medium category with 194 respondents $(52.43 \%)$. Whereas $111(30 \%)$ are in strong category, and $65(17.57 \%)$ are in weak category. That company has freed employees to innovate, appreciate employee innovation but the other hands company not train employees to be responsible for their mistakes. In McKinsey's research by Sull (2015), employee innovation was not optimal because many work regulations and standards applied.

This is also in line with Pribadi and Herlena (2016) research showing Steel Manufacture in Cilegon, Indonesia has applied organizational culture in the medium category on innovative aspects. So if the manufacturing companies have an organizational culture on innovation and risk taking aspects, they will tend to be moderate. Following Table 3.Organizational Culture Categorization on Aspects of Attention to Detail:

Table 3. Organizational Culture Categorization on Aspects of Attention to Detail

\begin{tabular}{cccc}
\hline Score limit & Score & Categorization & Total \\
\hline $\mathbf{X}>(\boldsymbol{\mu}+\mathbf{1 . 5} \boldsymbol{\sigma})$ & $\mathrm{X}>11.70$ & Very strong & $51(13.79 \%)$ \\
\hline$(\boldsymbol{\mu}+\mathbf{0 . 5} \boldsymbol{\sigma})<\mathbf{X} \leq(\boldsymbol{\mu}+\mathbf{1 . 5} \boldsymbol{\sigma})$ & $10.33<\mathrm{X} \leq 11.70$ & Strong & $46(12.43 \%)$ \\
\hline$(\boldsymbol{\mu} \mathbf{- 0 . 5} \boldsymbol{\sigma})<\mathbf{X} \leq(\boldsymbol{\mu}+\mathbf{0 . 5} \boldsymbol{\sigma})$ & $8.94<\mathrm{X} \leq 10.33$ & Medium & $220(59.46 \%)$ \\
\hline$(\boldsymbol{\mu} \mathbf{- 1 . 5} \boldsymbol{\sigma})<\mathbf{X} \leq(\boldsymbol{\mu} \mathbf{- 0 . 5} \boldsymbol{\sigma})$ & $7.56<\mathrm{X} \leq 8.94$ & Weak & $41(11.08 \%)$ \\
\hline $\mathbf{X} \leq(\boldsymbol{\mu} \mathbf{- 1 . 5} \boldsymbol{\sigma})$ & $\mathrm{X} \leq 7.56$ & Very weak & $12(3.24 \%)$ \\
\hline & TOTAL & & $\mathbf{3 7 0}(\mathbf{1 0 0 \%})$ \\
\hline
\end{tabular}

Organizational culture in comestible manufacture company on the aspect of attention to detail is greater in percentage in the medium category, with 220 respondents $(59.46 \%)$. Whereas 97 respondents $(26.22 \%)$ considered that the company was solid in terms of strength. And 53 respondents $(14.32 \%)$ considered on weak category. This shows the company has enough attention to the accuracy of the details of the work, the environment requires employees to work according to the procedure. However on other indicators considered less supportive behaviors are not careful as boss pointed to work carefully and superiors didn't work honestly and accurately because its not supervised by the manager. 


\section{International Advanced Research Journal in Science, Engineering and Technology}

Vol. 6, Issue 4, April 2019

According to Robbins and Judge (2015) at the dominant values in a manufacturing company is to produce a quality product so that it will require workers to pay attention to work details to maintain product quality. So that the company should apply the values of accuracy to working. Following Table 4. Organizational Culture Categorizationon Aspects of Orientation Towards Results:

Table 4. Organizational Culture Categorization on Aspects of Orientation Towards Results

\begin{tabular}{cccc}
\hline Score limit & Score & Categorization & Total \\
\hline $\mathbf{X}>(\boldsymbol{\mu}+\mathbf{1 . 5} \boldsymbol{\sigma})$ & $\mathrm{X}>15.99$ & Very strong & $72(19.46 \%)$ \\
\hline$(\boldsymbol{\mu}+\mathbf{0 . 5} \boldsymbol{\sigma})<\mathbf{X} \leq(\boldsymbol{\mu}+\mathbf{1 . 5} \boldsymbol{\sigma})$ & $14.32<\mathrm{X} \leq 15.99$ & Strong & $43(11.62 \%)$ \\
\hline$(\boldsymbol{\mu} \mathbf{- 0 . 5} \boldsymbol{\sigma})<\mathbf{X} \leq(\boldsymbol{\mu}+\mathbf{0 . 5} \boldsymbol{\sigma})$ & $12.66<\mathrm{X} \leq 14.32$ & Medium & $118(31.89 \%)$ \\
\hline$(\boldsymbol{\mu}-\mathbf{1 . 5} \boldsymbol{\sigma})<\mathbf{X} \leq(\boldsymbol{\mu} \mathbf{- 0 . 5} \boldsymbol{\sigma})$ & $10.99<\mathrm{X} \leq 12.66$ & Weak & $133(35.95 \%)$ \\
\hline $\mathbf{X} \leq(\boldsymbol{\mu} \mathbf{- 1 . 5} \boldsymbol{\sigma})$ & $\mathrm{X} \leq 10.99$ & Very weak & $4(1.08 \%)$ \\
\hline & TOTAL & & $\mathbf{3 7 0}(\mathbf{1 0 0 \%})$ \\
\hline
\end{tabular}

Organizational culture in comestible manufacture company of orientation towards the results aspect is greater percentage in the weak category as many 137 respondents (37.03\%). Whereas 115 respondents (31.08\%) their companies as being of moderate quality. And 118 respondents $(31.89 \%)$ considered being in the strong category. The factor of this problem, are management and superiors have not provided clear about work targets and not directed conditions to focus on targets and conducive to maximizing work outcomes. Besides it, employee have not focus to achieve employment targets, because compensation or job title is does not fit. It can be seen that more respondents are in the 1-3 year work period which tends short, so is not easy to produce satisfactory performance. Winter (1984) revealed, not achieve maximum work becaused by a new member on organization. This line with Wulan et al. (2015) research shows PT . PLN (Persero) Area X still has a less work environment towards work results oriented. Following Table 5. Organizational Culture Categorization on Aspects of Orientation Towards Individuals:

Table 5. Organizational Culture Categorization on Aspects of Orientation Towards Individuals

\begin{tabular}{cccc}
\hline Score limit & Score & Categorization & Total \\
\hline $\mathbf{X}>(\boldsymbol{\mu}+\mathbf{1 . 5} \boldsymbol{\sigma})$ & $\mathrm{X}>14.75$ & Very strong & $27(7.30 \%)$ \\
\hline$(\boldsymbol{\mu}+\mathbf{0 . 5} \boldsymbol{\sigma})<\mathbf{X} \leq(\boldsymbol{\mu}+\mathbf{1 . 5} \boldsymbol{\sigma})$ & $12.70<\mathrm{X} \mathrm{14.75}$ & Strong & $74(20 \%)$ \\
\hline$(\boldsymbol{\mu} \mathbf{- 0 . 5} \boldsymbol{\sigma})<\mathbf{X} \leq(\boldsymbol{\mu}+\mathbf{0 . 5} \boldsymbol{\sigma})$ & $10.66<\mathrm{X} \mathrm{12.70}$ & Medium & $188(50.81 \%)$ \\
\hline$(\boldsymbol{\mu}-\mathbf{1 . 5} \boldsymbol{\sigma})<\mathbf{X} \leq(\boldsymbol{\mu} \mathbf{- 0 . 5} \boldsymbol{\sigma})$ & $8.61<\mathrm{X} \leq 10.66$ & Weak & $53(14.32 \%)$ \\
\hline $\mathbf{X} \leq(\boldsymbol{\mu} \mathbf{- 1 . 5} \boldsymbol{\sigma})$ & $\mathrm{X} \leq 8.61$ & Very weak & $28(7.57 \%)$ \\
\hline & TOTAL & & $\mathbf{3 7 0}(\mathbf{1 0 0 \%})$ \\
\hline
\end{tabular}

Organizational culture in comestible manufacture company on orientation toward individual greater percentage in the medium category as many 188 respondents (50.81\%). While 101 respondents (27.30\%) assume the company has strong category. And 81 respondents (21.89\%) considered being in the weak category. Management of companies consider the capabilities and capacities of workers, adjusted the regulations taken to the needs of employees, set regulations without burdening employees. On the other hand, manufacturing management start abolished overtime to narrow the opportunities for employees overtime. The orientation aspect towards individuals has not been fully done by considering employees. According to Supriyanto (2016) organizations that provide opportunities to interact to produce decisions that pay attention to employees will strengthen organizational culture, so it is important to do. Following Table 6. Organizational Culture Categorization on Aspects of Orientation to the Team:

Table 6. Organizational Culture Categorization on Aspect of Orientation on the Team

\begin{tabular}{cccc}
\hline Score limit & Score & Categorization & Total \\
\hline $\mathbf{X}>(\boldsymbol{\mu}+\mathbf{1 . 5} \boldsymbol{\sigma})$ & $\mathrm{X}>11.70$ & Very strong & $35(9.46 \%)$ \\
\hline$(\boldsymbol{\mu}+\mathbf{0 . 5} \boldsymbol{\sigma})<\mathbf{X} \leq(\boldsymbol{\mu}+\mathbf{1 . 5} \boldsymbol{\sigma})$ & $10.33<\mathrm{X} \leq 11.70$ & Strong & $65(17.57 \%)$ \\
\hline$(\boldsymbol{\mu} \mathbf{- 0 . 5} \boldsymbol{\sigma})<\mathbf{X} \leq(\boldsymbol{\mu}+\mathbf{0 . 5} \boldsymbol{\sigma})$ & $8.94<\mathrm{X} \leq 10.33$ & Medium & $185(50 \%)$ \\
\hline$(\boldsymbol{\mu}-\mathbf{1 . 5} \boldsymbol{\sigma})<\mathbf{X} \leq(\boldsymbol{\mu} \mathbf{- 0 . 5} \boldsymbol{\sigma})$ & $7.56<\mathrm{X} \leq 8.94$ & Weak & $65(17.57 \%)$ \\
\hline $\mathbf{X} \leq(\boldsymbol{\mu}-\mathbf{1 . 5} \boldsymbol{\sigma})$ & $\mathrm{X} \leq 7.56$ & Very weak & $20(5.40 \%)$ \\
\hline & TOTAL & & $\mathbf{3 7 0}(\mathbf{1 0 0 \%})$ \\
\hline
\end{tabular}

Organizational culture incomestible manufacture company on orientation aspect of the team has a greater percentage which in the medium category, which is 185 respondents $(50 \%)$. While $100(27.03 \%)$ assessed that the company was in a strong category. And 85 respondents $(22.97 \%)$ considered being in the weak category. Employees assess the company has emphasized the achievement of the division in addition to personal achievement, and attitude of mutual cooperation to produce maximum team achievement. However, its still not optimal, for example, boss who's passive in managing to solid team and optimistic, and perhaps there is no appreciation for the results of teamwork if get 


\title{
International Advanced Research Journal in Science, Engineering and Technology
}

\author{
Vol. 6, Issue 4, April 2019
}

satisfactory results. According to Mary and Robbins (2010) ways of working groups held by the members of the organization will be of value and greatly affect how an organization run. So that on medium category in team orientation will form organizational culture in the medium category. Following Table 7. Organizational Culture Categorization on Aspects of Aggressiveness:

Table 7. Organizational Culture Categorization on Aspects of Aggressiveness

\begin{tabular}{cccc}
\hline Score limit & Score & Categorization & Total \\
\hline $\mathbf{X}>(\boldsymbol{\mu}+\mathbf{1 . 5} \boldsymbol{\sigma})$ & $\mathrm{X}>14.95$ & Very strong & $39(10.54 \%)$ \\
\hline$(\boldsymbol{\mu}+\mathbf{0 . 5} \boldsymbol{\sigma})<\mathbf{X} \leq(\boldsymbol{\mu}+\mathbf{1 . 5} \boldsymbol{\sigma})$ & $12.93<\mathrm{X} \leq 14.95$ & Strong & $80(21.62 \%)$ \\
\hline$(\boldsymbol{\mu} \mathbf{- 0 . 5} \boldsymbol{\sigma})<\mathbf{X} \leq(\boldsymbol{\mu}+\mathbf{0 . 5} \boldsymbol{\sigma})$ & $10.91<\mathrm{X} \leq 12.93$ & Medium & $183(49.46 \%)$ \\
\hline$(\boldsymbol{\mu} \mathbf{- 1 . 5} \boldsymbol{\sigma})<\mathbf{X} \leq(\boldsymbol{\mu} \mathbf{- 0 . 5} \boldsymbol{\sigma})$ & $8.95<\mathrm{X} \leq 10.91$ & Weak & $49(13.24 \%)$ \\
\hline $\mathbf{X} \leq(\boldsymbol{\mu} \mathbf{- 1 . 5} \boldsymbol{\sigma})$ & $\mathrm{X} \leq 8.95$ & Very weak & $19(5.14 \%)$ \\
\hline & TOTAL & & $\mathbf{3 7 0}(\mathbf{1 0 0 \%})$ \\
\hline
\end{tabular}

The organizational culture in comestible manufacture company on aggressiveness aspect in middle category as many 183 respondents (49.46\%). While 119 respondents (32.16\%) rated the company has strong culture. And 68 respondents $(18.38 \%)$ rated their company having a weak organizational culture on aggressiveness aspect. The company is considered to have encouraged in conducive environment to compete, employees try to arrive on time to immediately start work, create a conducive working atmosphere between departments and individuals. On the other hand there is still no maximum support from the company such as the absence of reward for employees who can show maximum performance so that management support is considered not optimal. This is also caused by the demographic factors of respondents who tend to be more in the age group of 20-30 years. In Goran's (2017) study, organizational culture that can compete in the digital age requires an aggressive work culture to compete and more easily build younger workers. So that youth workers compete to be the best worker will strengthen an aggressive organizational culture, even though it is still weak in other indicators of behavior. Following Table 8. Organizational Culture Categorization on Aspects of Stability

Table 8. Organizational Culture Categorization on Aspects of Stability

\begin{tabular}{cccc}
\hline Score limit & Score & Categorization & Total \\
\hline $\mathbf{X}>(\boldsymbol{\mu}+\mathbf{1 , 5} \boldsymbol{\sigma})$ & $X>15.09$ & Very Strong & $33(8.92 \%)$ \\
\hline$(\boldsymbol{\mu}+\mathbf{0 , 5} \boldsymbol{\sigma})<\mathbf{X} \leq(\boldsymbol{\mu}+\mathbf{1 , 5} \boldsymbol{\sigma})$ & $13.26<X \leq 15.09$ & Strong & $51(13.78 \%)$ \\
\hline$(\boldsymbol{\mu} \mathbf{0 , 5} \boldsymbol{\sigma})<\mathbf{X} \leq(\boldsymbol{\mu}+\mathbf{0 , 5} \boldsymbol{\sigma})$ & $11.44<\mathrm{X} \leq 13.26$ & Medium & $199(53.78 \%)$ \\
\hline$(\boldsymbol{\mu}-\mathbf{1 , 5} \boldsymbol{\sigma})<\mathbf{X} \leq(\boldsymbol{\mu}-\mathbf{0 , 5} \boldsymbol{\sigma})$ & $9.61<\mathrm{X} \leq 11.44$ & Weak & $68(18.38 \%)$ \\
\hline $\mathbf{X} \leq(\boldsymbol{\mu}-\mathbf{1 , 5} \boldsymbol{\sigma})$ & $X \leq 9.61$ & Very Weak & $19(5.14 \%)$ \\
\hline & TOTAL & & $\mathbf{3 7 0}(\mathbf{1 0 0 \%})$ \\
\hline
\end{tabular}

Organizational culture in comestible manufacture company on the aspect of stability to maintain the status quo has a greater percentage in the medium category as many 199 respondents $(53.38 \%)$. Whereas 84 respondents $(22.70 \%)$ assessing the company has strong culture. And 87 respondents $(23.52 \%)$ considered in the weak category. Employees assess the company where they work can maintain orderliness in the work environment, and leaders provide awareness for employees to always show maximum performance to maintain company profits. On the other hand there are still weaknesses such as not inspiring employees to maintain cooperation so that they always competition and trigger job stress. This in line with the research conducted by Damayanti and Fakhri (2013) which shows that employees are still disobedient in working and tendency to have a weak organizational culture in terms of maintain stability.

Employee Compliance. To make it easier to discuss the results, researcher grouping the categories very high and high into high categories, and low and very low become low categories in each discussion. To determine the category limits, standard deviation and average values are used. As for the of compliance, the researcher divides it into a whole to see overall categorization and also to categorize each indicator to see trends in the indicator. The minimum theoretical value for employee compliance is 21 , while the maximum value is 48 . The mean $(\mu)$ is 37.82 and the standard deviation value $(\sigma)$ is 4.61. The following table 9. Employee Compliance Categorization:

Table 9. Employee Compliance Categorization

\begin{tabular}{cccc}
\hline Score Limit & Score & Categorization & Total \\
\hline $\mathbf{X}>(\boldsymbol{\mu}+\mathbf{1 . 5} \boldsymbol{\sigma})$ & $\mathrm{X}>44.72$ & Very high & $42(11.35 \%)$ \\
\hline$(\boldsymbol{\mu}+\mathbf{0 . 5} \boldsymbol{\sigma})<\mathbf{X} \leq(\boldsymbol{\mu}+\mathbf{1 . 5} \boldsymbol{\sigma})$ & $40.12<\mathrm{X}<44.72$ & High & $49(13.24 \%)$ \\
\hline$(\boldsymbol{\mu} \mathbf{- 0 . 5} \boldsymbol{\sigma})<\mathbf{X} \leq(\boldsymbol{\mu}+\mathbf{0 . 5} \boldsymbol{\sigma})$ & $35.52<\mathrm{X}<40.12$ & Medium & $201(54.32 \%)$ \\
\hline$(\boldsymbol{\mu} \mathbf{- 1 . 5} \boldsymbol{\sigma})<\mathbf{X} \leq(\boldsymbol{\mu} \mathbf{- 0 . 5} \boldsymbol{\sigma})$ & $30.91<\mathrm{X} \leq 35.52$ & Low & $66(17.84 \%)$ \\
\hline $\mathbf{X} \leq(\boldsymbol{\mu} \mathbf{- 1 . 5} \boldsymbol{\sigma})$ & $\leq 30.91$ & Very low & $12(3.25 \%)$ \\
\hline & TOTAL & & $\mathbf{3 7 0}(\mathbf{1 0 0 \%})$ \\
\hline
\end{tabular}




\section{International Advanced Research Journal in Science, Engineering and Technology}

Vol. 6, Issue 4, April 2019

Employee compliance in comestible manufacture company is in medium category with 201 respondents $(54.32 \%)$. While 91 respondents $(24.59 \%)$ considered to having high compliance. And 78 respondents $(21,08 \%)$ considered had low compliance employees. Employees feel that they have a moderate level of expertise, that is feeling confident and accepting well that compliance will provide positive things and prevent workplace accidents, however who employees still have not been sincere in doing. In the research conducted by Irawati and Silalahi (2015), it was also explained that discipline problems and disobeying regulations were still found in manufacturing employees. On the other hand, in McKinsey report by Sull (2015) shows that there are several companies abroad have now begun to strengthen it to improve compliance by innovation, so that it always spurs workers to obediently innovate. In addition, of younger workers, they tend to be more obedient when compared to senior workers. Respondents likely to have 20-30 years old also shows that their tendency is to being quite obedient. Aisyah (2016) revealed that senior employees not to obey and endanger. And respondents more woman employee rather man and Hibau (2018) said that women employees are to be superior in terms of compliance.

In low categories, it shows there are still found in respondents who have not adhered to the SOP in the company, less appreciative of the form of norms that are enforced, do not carry out orders from superiors in the context of work, and even lack sample figures to strengthen them in adhering to company regulations and standard work procedures. In the McKinsey report conducted by Alberthet al. (2012) showed that in the ten years there were still phenomena of noncompliance of employees towards regulations and work instructions in banking companies.

All aspects of compliance. Aspect on compliance are belief, accept, and act. In all aspects of employees compliance in comestible manufacture company are in the medium category. Employees complying with belief aspect is greater percentage in 220 respondents $(59.46 \%)$, on the accept aspect greater percentage in 230 respondents $(62.16 \%)$. And on act aspects are greater percentage as many 208 respondents $(56.22 \%)$. Employees has shown behavior that is directed at compliance, such as believing that compliance with regulations and work procedures will security provide for workers, except that employees have not fully complied. Employees accept company rules without confrontation and receive penalties if they do mistakes or missions, but have not been able to invite the environment to voluntarily comply with the rules. As for employees, they have made compliance, such as arriving on time and always following procedures, but in doing so employees have not done it consistently, so that they are in the medium category.

This influenced by many factors, one of which is the demographics of the respondents. Respondents are more likely to 1-3 years work period of are considered more compliant compared to senior workers and this in line with the research conducted by Aisyah (2016) at chemical company in Java, Indonesia. On the age factor, employee with age 20-30 are classified as late adolescents will tend to react more easily if there are very strict regulations. In addition to gender, women are perceived to be more obedient in using uniforms, but on the other hand more often come late when compared to men because they have to settle their family affairs before go to work. This in line with the research conducted by Hibau (2018) which shows that women are said to be superior in terms of compliance. The Following Table 10. Employee Compliance on Conformity Aspect:

Table 10. Employee Compliance on Conformity Aspect

\begin{tabular}{cccc}
\hline Score Limit & Score & Categorization & Total \\
\hline $\mathbf{X}>(\boldsymbol{\mu}+\mathbf{1 , 5} \boldsymbol{\sigma})$ & $>11.58$ & Very High & $45(12.16 \%)$ \\
\hline$(\boldsymbol{\mu}+\mathbf{0 , 5} \boldsymbol{\sigma})<\mathbf{X} \leq(\boldsymbol{\mu}+\mathbf{1 , 5})$ & $10.22<\mathrm{X} \leq 11.58$ & High & $38(10.27 \%)$ \\
\hline$(\boldsymbol{\mu} \mathbf{- 0 , 5} \boldsymbol{\sigma})<\mathbf{X} \leq(\boldsymbol{\mu}+\mathbf{0 , 5} \boldsymbol{)})$ & $8.86<\mathrm{X} \leq 10.22$ & Medium & $250(67.57 \%)$ \\
\hline$(\boldsymbol{\mu}-\mathbf{1 , 5} \boldsymbol{\sigma})<\mathbf{X} \leq(\boldsymbol{\mu}-\mathbf{0 , 5} \boldsymbol{\sigma})$ & $7.50<\mathrm{X} \leq 8.86$ & Low & $25(6.76 \%)$ \\
\hline $\mathbf{X} \leq(\boldsymbol{\mu}-\mathbf{1 , 5} \boldsymbol{\sigma})$ & $\mathrm{X} \leq 7.50$ & Very Low & $12(3.24 \%)$ \\
\hline & TOTAL & & $\mathbf{3 7 0}$ \\
\hline
\end{tabular}

Employee compliance in terms of conformity is in medium category, with the most respondents are 250 respondents $(67.57 \%)$. While 83 respondents $(22.43 \%)$ considered having high compliance. And 37 respondents $(10 \%)$ considered having a level of employee compliance that was in the low category. This shows that the level of conformity influences employees compliance enough by influencing the environment to comply with regulations, reminding friends to obedient, but not modeling behavior that adheres to the environment to achieve uniformity. This also possible because of the greater factor of respondents working as staff, so that it seems that the level of conformity can be done easily on staff because staff have more opportunities to group with friends whom they consider the same and will try to equalize their environment. According to Federich (2012) social conformity provides a social influence that aims for individuals to change their attitudes and behavior in accordance with existing social norms. So that management can improve the form of conformity to make it easier to achieve company goals, namely an environment that is obedient and obedient in comparative analysis. In comparative analyzes were conducted to prove whether the stronger the culture of the organization it will be the higher the level of compliance of its employees. The results show there are 


\section{International Advanced Research Journal in Science, Engineering and Technology}

Vol. 6, Issue 4, April 2019

differences between the height and low compliance of employees with strong and weak organizational culture. On the other hand, there is also a difference between the high and the low compliance of employees on belief, accept and act aspects with strong and weak organizational culture. This also shows there is a connection between the two. So that by strengthening the organizational culture will improve employee compliance. This in line with Fakhri (2013) research shows that there are still employees who arrive late at work lacking an indecisive organizational culture to maintain employee compliance.

\section{RESEARCH FINDINGS}

In comestible manufacture company ideally have work result oriented employee in organizational culture. Productivities are important for the company's profits. However, this study shows different results. The organizational cultureon orientation towards results aspects in comestible manufacture company in Indonesia is in the weak category. This is contrary to the main purpose and obligation of employees to improve work outcomes. So that this becomes a new finding that the organizational culture of comestible manufacture company in Indonesia has not led employees to be oriented towards maximal work results.

\section{CONCLUSION}

Profile of the object of the research that the respondents have a greater percentage in the age range of 20-30 years. For respondents of female percentage is greater than men. For respondents who have a final education S1/D4 the percentage is greater when compared to other education levels. for respondents who have a tenure of 1-3 years, the percentage is greater when compared to other years of working periode. And more respondents in this study are currently working on staff positions. Organizational culture categorization of respondents representing employees in comestible manufacture company in Indonesia tends to be larger in the medium category and on aspects of innovation and risk taking, attention to detail, orientation to individuals, orientation to the team, aggressiveness and stability percentage is greater in the medium category. While the orientation of the results in the low category. Employees compliance are in the medium category and on aspects of belief, accepting and act percentage is greater in the medium category. The categorization of employee compliance on aspects of conformity is greater in the medium category. In comparative analyzes, there is a difference between the high and the low compliance of employees with strong and its weak organizational culture. And there are also differences between the high and low compliance of employees on the aspect of belief, accept and act with strong and weak organizational culture. So, as to stronger the organizational culture will be the higher the level of compliance of employees and also that the stronger the organizational culture will be the higher the level of compliance of employees in the aspect of belief, accept and act.

\section{RESEARCH LIMITATIONS}

The research still had limitations in taking research samples that were not too broad. On the results of data processing that tends to be making high and low the culture of employee organization and compliance is not very visible. In profile of the research object, the population tends to be more than 1-3 years working period, so it tends to be new in assessing the organizational culture in the company. In addition, respondents who tended to work more as staff made their judgments tend to follow as far as their role as staff who obeyed the rules in the company.

\section{SUGGESTIONS FOR FUTURE RESEARCH}

Suggestions for future research are expected to be able to conduct research with different samples, such as company employees with other business fields according to the phenomena in the field. In addition, research can be done by linking organizational culture or employee compliance with other variables or with other factors that can influence such as employee satisfaction, work motivation, self-efficacy, work management. Researchers can also conduct research on employees who have a working period of more than 5 years in the company so they can be with strongly assess the company more objectively. For the categorization range, it can also give variation by eliminating the medium category, so that it does not look biased and can see the high and low results of the data distribution more clearly.

\section{REFERENCES}

[1]. Aisyah, SN (2016.) Relationship between Compliance with Work Instructions and Safe Behavior in Employees of the Mechanical Section of PT. Indo AcidatamaTbk, Kemiri, Kebakkaramat, Karanganyar. Journal of Public Health. Vol. 17. No.2, 1-12.

[2]. Alberth, S., Babel, B., Becker, D., Kaltenbrunner, D., Poppensieker, T., Schneider, S., Stegemen, U., \& Wegner, T. (2012). Compliance and Control 2.0 Unlocking Potential trhough Compliance And Quality Control Activities. McKinsey Report.

[3]. Blass, T. (1999). The Milgram Paradigm After 35 Years: Some Things We Now Know About Obedience to Authority. Journal of Applied Social Psychology. Vol. 29, No.5, 955-978. 


\title{
International Advanced Research Journal in Science, Engineering and Technology
}

\author{
Vol. 6, Issue 4, April 2019
}

[4]. Brown, B. (2009). Perceptions of student misconduct, perceived respect for teachers, and support for corporal punishment among school teachers in South Korea: An exploratory case study. Journal Educational Research for Policy and Practice.Vol 8. No 1, 3-22.

[5]. Brury, M. (2016). The Effect of Leadership, Organizational Culture, Work Motivation and Job Satisfaction on the Performance of Employees at the Sorong SAR Office. Journal of Business Research and Management. Vol. 4. No.1, 1-16.

[6]. Chen, L. Y. (2004). Examining The Effect of Organization Culture \& Leadership Behaviors on Organizational Commitment, Job Satisfaction, \& Job Performance at Small \& Middle-Sized Firms of Taiwan. Journal of American Academy of Business, Vol 5, No. 2, $432-438$.

[7]. Damayanti, D.,\&Fakhri. M. (2013). The Influence of Organizational Culture on Employee Discipline of PT AngkasaPura II (Persero) Main Branch Office of Soekarno-Hatta International Airport on General Affairs Personnel Unit. Business Administration Jour. Vol. XVI. No.2, 1-14.

[8]. Deal, T.E. and Kennedy, A.A. (1982). Corporate cultures: The Rites and Rituals of Corp Life. Reading, Mass: Addison-Wesley Publishing Co.

[9]. Franklin, AL, \& Pagan, JF (2016) Organizational Culture As Explanation For Employee Discipline Practice. Public Personnel Administration . Vol. 26. No. 1, 52-73

[10]. Federich. (2012) Conformity, Obedience to Authority and Compliance Without Pressure to Control Cigarette Butt Pollution. Journal of Social Influence. Vol 9. No. 2,83-98

[11]. Goran, J., LaBerge, L., Srinivasan, R. (2017). "Culture of Digital Age". McKinsey Quartely.

[12]. Hibau. (2018). Work Discipline for Employees Based on Gender Equality in Long Pahangai Sub-District Office, Mahakam Ulu District. Journal of Integrative Governance. Vol 6. No. 2, 263-272.

[13]. Irawati, R., \&Silalahi, E (2015). The Effect of Work Discipline and Organizational Culture on Production Operator Performance at PT. XXX. Journal of Accounting, Economics and Business Management. Vol. 3 No. 2, 115-119.

[14]. Jaghargh, ZF, Ghorbanpanah, H., Nabavi, SE (2012). A survey on Stephanie Robbin's theory based theory on culture based (Case Study). 2012 2nd International Conference on Management and Artificial Intelligence IPEDR Singapore . Vol. 35. No. 6, 30-34.

[15]. Kelman, HC (1958). Compliance, identification, and internalization three process of attitude change. Journal of conflicsolution . Vol. II. No. 1, 51-60.

[16]. Kreitner, R., \&Kinicki, A. (2014). Organizational behavioral (5 $5^{\text {th }}$ ed.). Boston: McGraww-Hill.

[17]. Maseko, S.B.T. (2017). Strong vs. Weak Organisational Culture: Assessing the Impact on Employee Motivation. Arabian Business Management Review. Vol. 7. No. 1, 1-5

[18]. McKinsey \& Company. (2016). Diagnosis on the Organizational Health and Corporate Culture of Korean Companies. Korea: Author.

[19]. Milgram, S. 1963. Behavioral study of Obedience.Jornal of Obedience.Volume 1. No 1, 1-5.

[20]. NN. Law No. 5 of 1984 About: Industry. Obtained in July, 3 2018.Downloaded from http://pelayanan.jakarta.go.id/regulation oflaw-number-5year-1984concern- perindustrian.pdf.

[21]. Noonan, K. (2017). The Similiraties and Differences of Work Culture in the United Kingdom vs. America . Retrieved July, 19 ${ }^{\text {th }} 2018$. From https://footholdamerica.com/.

[22]. Mary \& Robbins.(2010). Manajemen Edisi Kesepuluh Jilid 1.Jakarta :Erlangga

[23]. Odor, H.O (2018). Organizational culture and dynamics. Journal of Management and Business Research. Vol. 18. No. 1, $22-27$.

[24]. Pribadi, M. L \&Herlena, B. (2016). Organizational Culture of Work Discipline Employees of the Production Directorate of PT. Krakatau Steel (Persero) Tbk Cilegon Communication Journal . Vol.3. No. 2, 1 - 22.

[25]. Rahmawati, A. D., \& Lestari, L. (2015). Obedience of Santri to Rules in Modern Islamic Boarding Schools. National Seminar Proceedings . iSBN: 978-602-71716-3-3, 19-28.

[26]. Robbins and Judge. (2015). Organizational Behavior Sixteen Edition. Kendallville: Global Edition

[27]. Salamadian. (2017). Manufacturing Companies: Definition, Example of List of IDX Manufacturing Companies . Obtained in July, 05 2018. Downloaded from https://salamadian.com/company-manufacturing

[28]. Schein, H.E (2010). Organizational Culture and Leadership $4{ }^{\text {th }}$ Edition. San Francisco: Jossey-Bass.

[29]. Sterwart, D.
Retrieved on February, $10^{\text {th }} 2019$ From https://www.wachovia.com/ foundation/ v/ind he Corporate

Culture. Retrieved on February, $10^{\text {th }} 2019$ From https:/www.wachovia.com/ foundation/ v/index.jsp? vgnextoid=ab411f07760aa110VgnV CM1000004b 0d1872

[30]. Sull, D. (2015). McKinsey Quartely The Simple Rules of Disciplined Innovation. McKinsey Quartely

[31]. Winter. (1984). Comming to a Awareness of Organization Cultures. proQuest

[32]. Information and Learning Company . Vol. 25, No.2, 3-15

[33]. Wulan, D, P, A., Istiana.,Alam, S., Umar, F. (2015). The Effect of Job Stress and Motivation on Employee Satisfaction and Performance at PT. PLN (Persero) Merauke Area.Journal of Applied Business and Entrepreneurship.Vol 1, No.2, 1-14

[34]. Xiaoming, C, \&Juchen, H. (2012). A Literature Review on Organization Culture and Corporate Performance. International Journal of Business Administration. Vol. 3, No. 2, 28-37. 